\title{
Social Needs and Convictions as Predictors of Emotional and Psychological Well-being of College and University Students
}

\author{
Rail M. Shamionov \\ Marina V. Grigoryeva
}

Saratov State University, 410012, Astrakhanskaya st., 83, Saratov, Russia; e-mail: shamionov@info.sgu.ru

\author{
Doi:10.5901/mjss.2015.v6n6s1p528
}

\begin{abstract}
There have been very few investigations of emotional and psychological well-being associated with attitude to certain events, socio-political phenomena, and convictions of students at various stages of education. Therefore, studying emotional and psychological well-being and their predictors in college and university students is important for solving a number of practical problems, which psychological (counseling) services of an educational institution are faced with. The purpose of the present investigation is to carry out comparative analysis of social needs, convictions, satisfaction with various areas of reality, and predictors of emotional and psychological well-being in college and university students. 89 college students and 109 university students (66\% females) took part in the investigation. They filled out questionnaires aimed at identification of emotional and psychological well-being and expressiveness of convictions, social needs, and satisfaction with them. Differences in identification of emotional and psychological well-being can be traced at various levels of professional education. Convictions, social needs, and satisfaction of needs determine emotional well-being in college and university students. Tightness of interconnections between psychological well-being and convictions, social needs, satisfaction of needs is significantly higher in university students. Convictions, social needs and satisfaction of needs explain $40 \%$ of variations of emotional well-being in college students and $80 \%$ of variations of emotional well-being in university students. It is shown that variations in emotional well-being of university students are conditioned by social and political convictions, as well as satisfaction of vital needs, while in college students they are conditioned by satisfaction with life, with oneself and content of education.
\end{abstract}

Keywords: personality, emotional well-being, psychological well-being, social needs, convictions, satisfaction with life.

\section{Introduction}

Investigations of predictors of subjective well-being are important from the point of view of analysis of events in one's life, in the society, and personality, which determine its various levels. This type of knowledge is necessary for (1) more precise understanding of psychological nature of subjective well-being, and (2) development of psychological tools, which are aimed at rendering help to a person while adjusting, coping with difficulties, and in his/her self-fulfillment.

Personal attitude to social and political events, satisfaction of major needs can be differently reflected on experiencing emotional and psychological well-being. The nature of determination of subjective well-being can have its peculiarities and variations at every individual stage of life. This is due to the fact that social experience and personal development lead to actualization of various needs and various notional attitudes of a personality. It is obvious that education that one receives also promotes diversification of interests and opportunities of a personality. Thus, investigators point out that subjective well-being is linked to level of education (Argyle, 2001). However, there are discrepancies in understanding of mechanisms of education's influence on well-being.

Recently there have been many investigations of characteristics of subjective well-being in the process of receiving an education. It is linked to the necessity of identification of dynamics, structure and factors of students' subjective wellbeing in order to create optimal educational conditions in cases when ill-being is discovered, and help a student to achieve an optimal state. Meanwhile, two sides of subjective well-being (emotional and psychological) are mostly studied separately, except in occasional investigations (Chen, Jing, Hayes, Lee, 2013). Thus, scientists discovered significant social and regional variations in markers of psychological well-being in students (Kornienko \& Kozlov, 2014), studied the dynamics of psychological (Kozmina, 2013) and emotional (Busseri \& Sadava, 2013) well-being of students during their studies, interconnection between personal characteristics and psychological well-being of students (Vodyakha, 2014; Safronova, \& Kuznetsova, 2014), interconnection between psychological well-being and strategies of students' adjustment (Ovchinnikov \& Sultanova, 2014), structural peculiarities of subjective well-being in first-year students 
(Shamionov, 2014), characteristics of students' emotional well-being in their interconnection with convictions (Shamionov, Grigoryeva, \& Grigoryev, 2014), interconnection between characteristics of friendship and social skills of students living in various countries (Demir, Jaafar, Bilyk, \& Ariff, 2012), as well as many other characteristics.

Investigations carried out by Sheldon and his colleagues showed that the contribution that various phenomena make to subjective well-being is not the same. Its various determinants form complex interconnected structures, which, when taken into consideration, can significantly help to predict changes in subjective well-being under various conditions. A particularly important place among them is taken by varying relations between a person and the society (Sheldon \& Hoon, 2007; Sheldon, Cheng, \& Hilpert, 2011).

Investigations of predictors of subjective well-being of students from various educational institutions (schools, colleges, universities) are currently linked with solution of a number of problems: adjustment and acculturation of migrant students (Yu \& Downing, 2012; Dorozhkin \& Mazitova, 2008; Brisset, Safdar, Lewis, \& Sabatier, 2010; Hui, Lent, \& Miller, 2013; Shoshani \& Slone, 2013; Ovchinnikov \& Sultanova, 2014), combination of satisfaction of needs and life goals (Shamionov, Grigoryeva, \& Grigoryev, 2014; Yashchenko, 2012; Wouters, Germeijs, Colpin, \& Verschueren, 2011), comparative analysis of well-being predictors in adolescents attending high-school and older adults (Butkovic, Brkovic, \& Bratko, 2012), predictors of subjective well-being during the period of school adjustment during the pivotal period of transition to middle school (Shoshani \& Slone, 2013; Shamionov, 2014), and a number of other problems.

Investigations concerning correlations between subjective well-being, emotional intellect of students (Chebanova, 2013), values, meanings (Pogorskaya, 2011), and protective reactions (Urivaev \& Tarasova, 2011) conclusively prove changeability of various factors of subjective well-being at different stages of students' education.

It is important to point out that subjective emotional well-being and psychological well-being of students are usually studied separately mostly due to the fact that there are certain discrepancies in theoretical approaches. Nevertheless, joint analysis of predictors of psychological and emotional well-being allows obtaining a wider picture of students' wellbeing and identifying to what degree perceptions and attitudes of students to various events make a contribution to changes in these types of well-being.

Investigations of interconnection or prediction of emotional and psychological well-being and attitude to certain events, social and political phenomena, as well as everyday situations involving students at various stages of education have hardly been carried out.

Therefore, the study of emotional and psychological well-being and their predictors in college and university students is important for identification of the contribution of the level of education to subjective well-being and its factors, as well as for solution of a range of problems, which a psychological service of an educational institution is faced with.

The purpose of the present investigation is to carry out comparative analysis of social needs, convictions, satisfaction with various areas of reality and predictors of emotional and psychological well-being in college and university students.

\section{Method}

\subsection{Participants and procedure}

The investigation was conducted during the first six months of the year 2014 in Russia. A college in the Russian educational system is an educational institution which students enter having competed nine years of basic general education. College students can enter a university after completing a course in college in order to pursue a Bachelor's degree or Specialist's degree. A university can be entered upon the completion of eleven years at school and obtaining Certificate of complete secondary education. 89 first-to-fourth-year college students (median age 17.6, standard deviation 1.06) and 109 first-to-fourth-year university students (median age 18.8, standard deviation 1.25) took part in the investigation. Total number of people was 198. We used the stratified sampling method to form the sample. Participants were informed that there were no right or wrong answers, assured of the confidentiality of their responses and encouraged to ask questions if necessary. Completion of questionnaires took about $40 \mathrm{~min}$.

\subsection{Research Methods}

In the investigation we used the methods of testing, scaling, and questionnaires.

The following techniques were used: Perrudet-Badoux, Mendelsohn, Chiche scale of subjective well-being adapted by M.V. Sokolova (contains 17 items), which is aimed at identification of emotional component of subjective well-being.

K. Ryff's psychological well-being scale adapted by L.V. Zhukovskaya and E.G. Troshikhina (full version) 
(Zhukovskaya, Troshikhina, 2011) (contains 54 items). The technique contains 6 scales (autonomy, competence, personal growth, life goals, self-acceptance, and general index) and identifies the level of personal psychological wellbeing at a given stage of life.

Questionnaire. In order to evaluate characteristics of personal attitude to social events, convictions, satisfaction of one's needs, and satisfaction with life, satisfaction of the conditions of learning and self-satisfaction, we developed a number of scales (based on direct evaluation from 1 to 10 points: 1 - lack of characteristic, 10 - characteristic with maximum expressiveness). Indices of reliability-consistency were measured with Cronbach's alpha criterion (Table 1).

\subsection{Data analysis}

The following types of analysis were used: Student's t-test, Pearson's correlation analysis, direct step-by-step regression analysis. All statistical analyses were conducted with the aid of the Statistical Package for the Social Sciences (SPSS 20.0).

\section{Results}

Comparative analysis of the general index of subjective well-being in groups of college and university students allowed to uncover significant differences in its expressiveness (Student's $t=9.26, p<0,000$ ). University students in comparison to college students feel healthier, more active, they are more often in a good mood. University students are less bored, worried, lonely; they are more optimistic when they think about the future and less irritable. At that, it was discovered that indices of psychological well-being are practically the same.

Let us view some of the indices of relevance of needs, convictions, satisfaction with various areas of reality as factors of students' well-being (Table 1).

In general satisfaction with inter-national (inter-ethnic) relations was moderately expressed in both college and university students ( $M=5.8$ and $M=4.6$ points correspondingly with a maximum point of 10$)$. Comparative analysis conducted with Student's t-test showed that college students are more satisfied with inter-ethnic relations in the region where they live than university students (Student's $t=2.92, p<0.01$ ). For college students inter-ethnic relations are not as relevant as they are for university students. Colleges train professionals mostly for the region where they are located, therefore, the majority of college students are people from the region where the college is located. The national (ethnic) population of students largely resembles the ethnic composition of the region. Therefore, higher satisfaction with interethnic relations in the region in college students can be associated with socio-psychological adjustment and habitual wellformed patterns of inter-ethnic interactions. University students, studying under conditions of open education, have to widen inter-ethnic contacts, their social and psychological adjustment is actualized, which influences their experience of satisfaction with inter-ethnic relations.

Religious tolerance is better developed in college students than in university students (Student's $t=2.55, p<0.01$ ). College students more eagerly accept co-existence of multiple religions in the region where they live (Orthodox, Islam, Buddhism, Judaism, etc.). This could be possibly attributed to the fact that college students do not realize the importance of inter-confessional differences and problems, due to the fact that they are not relevant to them and students distance themselves from this type of problems.

Attitude of foreign countries to Russia and Russians is more important for college students than university students (Student's $t=2.63, p<.01$ ). It is obvious that university students are less oriented towards reflections about international relations; they are possibly more confident of correctness of the state policy, have a more mature and independent national consciousness. We can also assume that general internality in university students is less expressed, therefore, they perceive attitude of foreign countries to Russia and Russians as reality, which cannot be influenced by them. This assumption is supported by significant differences in evaluation of their abilities and opportunities to influence the events of their lives (Student's $t=2.97, p<.01$ ). In college students these evaluations are higher than in university students $(M=8.4$ and $M=7.6$ correspondingly). This brings us to the conclusion that educational environment in college generally fosters the development of internality and subjectness to a greater degree, supports active attitude to life in students.

We uncovered significant differences between college and university students concerning their readiness to give a helping hand to those who need it (Student's $t=4.6, p<0.000$ ). College students believe that their readiness to help those who need it is high $(M=9.02)$, in university students it is slightly higher than average (M=7.7). It is obvious that his fact also proves more developed subjectness and internality in college students.

College students have significantly higher evaluation of all criteria related to satisfaction than university students. Thus, general satisfaction with life in college students is 8.4 , while in university students it is at an average of 7.2 
(Student's $t=3.56, p<0.000$ ). It should be pointed out that both college and university students have generally high level of satisfaction with life, which is a psychological foundation for experiencing subjective well-being. However, the notions regarding the way of achieving subjective well-being in college and university are different. College students to a higher degree agree with the statement that happiness is peace, opportunity to enjoy without any effort (Student's $t=5.58$, $p<0.000$ ). It is noticeable that college students to a higher degree than university students prefer easiness of satisfaction of one's needs, lack of difficulties in achieving their goals, lack of problems in their life, while their subjectness and internality, which were mentioned above, are most likely to be declared or potential.

Due to the fact that one of the major components of subjective well-being is satisfaction of a subject with various aspects and conditions of carrying out significant activity in reality in general, let us view the specifics of satisfaction with educational process and components of educational environment in college and university students.

Similarly to university students, college students highly evaluate an opportunity of receiving qualitative rigorous education, which provides for their future ( $M=9$ and $M=8.4$ correspondingly), but college students evaluate this opportunity much higher than university students (Student's $t=2.52, p<0.01$ ). College students are to a higher degree satisfied with education that they are receiving, and consider it sufficient to provide for their lives. They see more opportunities for continuing their studies, which is understandable, because college studies can be viewed as a stage preceding university studies.

Table 1. Indices of relevance of needs, convictions, satisfaction with various areas of reality and their interconnection with emotional and psychological well-being in college and university students

\begin{tabular}{|c|c|c|c|c|c|c|c|c|c|c|c|}
\hline & \multirow[b]{2}{*}{$\begin{array}{c}\text { Alfa } \\
\text { Kronbahs }\end{array}$} & \multicolumn{2}{|c|}{ College } & \multicolumn{2}{|c|}{ University } & \multirow[b]{2}{*}{$\mathrm{t}$} & \multirow[b]{2}{*}{$\begin{array}{c}\text { Sig. } \\
\text { (2-tailed) }\end{array}$} & \multicolumn{2}{|c|}{ College } & \multicolumn{2}{|c|}{ University } \\
\hline & & M & $\mathrm{SD}$ & M & SD & & & $\begin{array}{l}\text { Emotional } \\
\text { well-being }\end{array}$ & $\begin{array}{l}\text { Psychological well- } \\
\text { being }\end{array}$ & $\begin{array}{l}\text { Emotional } \\
\text { well-being }\end{array}$ & $\begin{array}{l}\text { Psychological } \\
\text { well-being }\end{array}$ \\
\hline Relevance of material well-being of people around & .81 & 4.39 & 3.11 & 4.16 & 2.82 & 0.54 & .59 & -.10 & -.07 & -.10 & .14 \\
\hline Relevance of political stability in the region, state & .81 & 5.85 & 3.20 & 5.37 & 2.71 & -.57 & .57 & -.04 & -.09 & .14 & -.10 \\
\hline Relevance of democratic freedoms & .81 & 5.05 & 3.26 & 5.78 & 2.81 & -.24 & .81 & .00 & -.08 & -.02 & .08 \\
\hline Satisfaction with inter-ethnic relations in the region & .81 & 5.80 & 3.04 & 4.57 & 2.76 & 2.92 & .00 & $-.26^{*}$ & -.09 & -.04 & -.02 \\
\hline $\begin{array}{l}\text { Relevance of attitude of foreign countries to Russia } \\
\text { and Russians }\end{array}$ & .80 & 6.26 & 3.00 & 5.17 & 2.77 & 2.63 & .01 & -.05 & .03 & -.11 & $.20^{*}$ \\
\hline $\begin{array}{l}\text { Relevance of opportunities which the society } \\
\text { provides for free entrepreneurship, starting one's } \\
\text { own business }\end{array}$ & .81 & 6.44 & 2.65 & 6.36 & 2.60 & 0.21 & .84 & -.15 & -.01 & -.17 & .07 \\
\hline Relevance of career growth opportunities & .81 & 8.43 & 2.24 & 7.80 & 2.52 & 1.84 & .07 & $-.23^{*}$ & .02 & -.15 & .18 \\
\hline Relevance of interpersonal relations & .81 & 8.03 & 2.22 & 7.97 & 2.41 & 0.19 & .85 & -.12 & -.14 & -.14 & $.21^{\star}$ \\
\hline $\begin{array}{l}\text { Ability and opportunity to influence one's life } \\
\text { processes }\end{array}$ & .81 & 8.43 & 1.65 & 7.63 & 2.14 & 2.97 & .00 & $-.31^{t *}$ & .10 & $-.31^{\text {th }}$ & $.35^{\text {tk }}$ \\
\hline $\begin{array}{l}\text { Opportunity of receiving qualitative rigorous } \\
\text { education }\end{array}$ & .81 & 9.02 & 1.57 & 8.36 & 2.11 & 2.52 & .01 & -.07 & -.19 & $-.39^{\text {t*k }}$ & $.39^{* *}$ \\
\hline $\begin{array}{l}\text { Relevance of ecological problems on the planet, in } \\
\text { the region of residence }\end{array}$ & .81 & 7.16 & 2.77 & 6.68 & 2.52 & 1.27 & .20 & -.20 & -.08 & -.13 & $.20^{\star}$ \\
\hline $\begin{array}{l}\text { Notion of globalization, integration processes in the } \\
\text { economy }\end{array}$ & .81 & 4.27 & 2.62 & 4.49 & 2.66 & -.58 & .56 & -.16 & .09 & .02 & .13 \\
\hline $\begin{array}{l}\text { Ability and opportunity to influence the events, } \\
\text { which are taking place in the society }\end{array}$ & .80 & 5.62 & 2.69 & 5.08 & 2.72 & 1.38 & .17 & $-.31^{\star *}$ & -.10 & -.03 & .02 \\
\hline Readiness to help those who need it & .81 & 9.02 & 1.69 & 7.70 & 2.33 & 4.60 & .00 & -.04 & -.09 & $-.23^{*}$ & $.22^{*}$ \\
\hline Opportunity of self-realization in professional activity & .81 & 8.12 & 2.10 & 7.61 & 2.37 & 1.59 & .11 & $-.27^{*}$ & .01 & -.17 & $.38^{* *}$ \\
\hline $\begin{array}{l}\text { Strength of positive experiences linked to } \\
\text { progressive development of the society }\end{array}$ & .80 & 5.92 & 2.52 & 5.78 & 2.67 & 0.39 & .70 & $-.24^{*}$ & -.16 & $-.19^{*}$ & $.41^{* *}$ \\
\hline $\begin{array}{l}\text { Hope for changes for the better in the society and in } \\
\text { the world }\end{array}$ & .81 & 7.61 & 2.79 & 7.07 & 2.98 & 1.29 & .20 & $-.26^{*}$ & .01 & $-.21^{*}$ & $.19^{\star}$ \\
\hline Opportunity of interesting full life in the present & .81 & 8.49 & 2.21 & 8.18 & 2.18 & 1.02 & .31 & $-.35^{* *}$ & -.10 & -.18 & $.27^{* *+}$ \\
\hline Opportunity of interesting full life in the future & .81 & 8.37 & 2.44 & 8.31 & 2.08 & 0.20 & .84 & $-.22^{*}$ & -.19 & $-.25^{*+}$ & $.33^{* *}$ \\
\hline Degree of uncertainty in one's life & .86 & 6.35 & 1.97 & 6.19 & 2.84 & 0.15 & .88 & -.02 & $.22^{*}$ & .11 & -.17 \\
\hline $\begin{array}{l}\text { Positive attitude to the growing rhythm of life in the } \\
\text { society }\end{array}$ & .81 & 5.71 & 2.46 & 5.73 & 2.68 & -.06 & .95 & -.25 & -.11 & $-.19^{*}$ & $.39^{* *}$ \\
\hline $\begin{array}{l}\text { Possibilities of close interpersonal communication in } \\
\text { modern people }\end{array}$ & .81 & 6.94 & 2.75 & 6.58 & 2.94 & 0.88 & .38 & -.07 & -.12 & $-.22^{*}$ & .17 \\
\hline $\begin{array}{l}\text { Degree of humanness and "warmth" of contacts } \\
\text { between people in the society }\end{array}$ & .81 & 7.04 & 2.90 & 6.50 & 3.03 & 1.28 & .20 & -.06 & $-.21^{\star}$ & $-.21^{*}$ & $.35^{* *}$ \\
\hline $\begin{array}{l}\text { Acceptance of co-existence of different religions in } \\
\text { the region of residence }\end{array}$ & .81 & 6.75 & 3.10 & 5.64 & 3.00 & 2.55 & .01 & -.09 & -.11 & .06 & .02 \\
\hline Satisfaction with inter-ethnic relations in the region & .80 & 5.80 & 3.04 & 4.57 & 2.76 & 2.92 & .00 & $-.26^{*}$ & -.09 & -.04 & -.02 \\
\hline $\begin{array}{l}\text { Notion of happiness as peace, opportunity to enjoy } \\
\text { one's life without any effort }\end{array}$ & .80 & 7.60 & 2.76 & 5.42 & 2.70 & 5.57 & .00 & -.02 & .05 & -.08 & -.02 \\
\hline Satisfaction with life & .80 & 8.36 & 2.40 & 7.17 & 2.26 & 3.56 & .00 & $-.51^{\text {t* }}$ & -.10 & $-.34^{*+*}$ & $.35^{* *}$ \\
\hline Satisfaction with relations with teachers & .80 & 8.25 & 2.19 & 6.94 & 2.46 & 3.93 & .00 & $-.37^{*+}$ & -.12 & $-.28^{*+*}$ & $.26^{\text {*t }}$ \\
\hline Satisfaction with content of education one receives & .80 & 8.44 & 2.16 & 7.14 & 2.35 & 4.03 & .00 & $-.44^{*+*}$ & -.11 & $-.24^{*}$ & $.21^{*}$ \\
\hline Satisfaction with professional choice & .80 & 8.45 & 2.17 & 7.74 & 2.16 & 2.29 & .02 & $-.30^{\prime \prime \prime}$ & -.01 & -.09 & $.25^{* *}$ \\
\hline $\begin{array}{l}\text { Satisfaction with material security of the academic } \\
\text { process }\end{array}$ & .80 & 7.04 & 3.04 & 6.44 & 2.59 & 1.52 & .13 & $-.34^{* *}$ & -.15 & $-.23^{*}$ & $.21^{\star}$ \\
\hline Satisfaction with classrooms & .80 & 7.20 & 3.21 & 7.65 & 2.03 & -1.19 & .24 & $-.26^{*}$ & -.03 & -.02 & .15 \\
\hline
\end{tabular}


Satisfaction with possibility to eat good food

Satisfaction with design of classrooms

Satisfaction with relations in the group of students

Satisfaction with society's attitude to oneself

Satisfaction with one's appearance

Satisfaction with one's character

Satisfaction with one's abilities

$\begin{array}{llllll}.80 & 6.51 & 3.11 & 6.57 & 2.54 & -0.16 \\ .80 & 6.65 & 2.95 & 6.42 & 2.63 & 0.59 \\ .80 & 7.81 & 2.55 & 6.75 & 2.52 & 2.92 \\ .80 & 8.06 & 2.16 & 7.46 & 2.13 & 1.93 \\ .80 & 7.94 & 2.55 & 6.27 & 2.25 & 3.03 \\ .80 & 7.84 & 2.55 & 5.27 & 2.21 & 4.74 \\ .80 & 8.18 & 2.16 & 4.41 & 1.94 & 7.96\end{array}$

Notes: $)^{1}$ Reverse scale; $\left.)^{\star} p<0.05 ;\right)^{\star \star} p<0.01$

.88
.56
.00
.06
.00
.00
.00

\begin{tabular}{llll}
$-.22^{*}$ & -.01 & -.14 & $.21^{*}$ \\
$-.27^{*}$ & -.01 & -.09 & $.28^{* *}$ \\
-.17 & .02 & $-.28^{* *}$ & $.29^{* *}$ \\
-.18 & -.08 & $-.25^{*}$ & $.35^{* *}$ \\
$-.26^{*}$ & -.16 & -.21 & .07 \\
$-.46^{* *}$ & -.07 & .03 & .21 \\
$-.34^{* *}$ & -.06 & -.04 & -.01 \\
\hline
\end{tabular}

College students are more satisfied with their professional choice and content of education that they are receiving than university students (Student's $t=2.29, p<0.05 a n d t=4.03, p<.001$ ). It should be mentioned that university students who took part in the present investigation were liberal arts students; content of their future professional activity was similar and related to interaction with people. Nevertheless, college students have a more positive attitude to both education and their future professional activity. As a consequence, college students are more satisfied with their relations with teachers and relations with their group mates than university students (Student's $t=3.93 p<, 001$ and $t=2.92, p<.01$ ). Thus, we can conclude that social component of college educational environment is more instrumental in forming subjective well-being than educational environment that is forming social relations at university. It is obvious that subjects of higher education are more demanding towards each other, the emotional background of their interactions is less positive, and the goal of maintaining good relations is not as important as it is for college students.

Satisfaction, which is conditioned by self-attitude, is significantly higher in college students. They are more satisfied with their appearance (Student's $t=3.03, p<, 01$ ), their character (Student's $t=5,58, p<, 001$ ), and their abilities (Student's $t=7.96, p<.001)$. It should be mentioned that satisfaction with appearance in both college and university students is higher than a possible average point $(M=7.9$ and $M=6.3$ correspondingly), while the differences are possibly explained by the fact that college students take more care about their appearance, pay more attention to the way they look, to fashion. Satisfaction with one's character is better expressed in college students than in university students $(M=7.8$ and $M=5.3$ correspondingly), which is obviously conditioned by more harmonious relations of college students with the requirements of the environment. In university educational environment the requirements to a student's personality are higher than in a college educational environment. Attitude of the environment under such conditions is more critical, less positive, to a greater extent linked to pragmatic goals rather than positive relations-linked goals. All of the above does not promote responding positive attitudes on behalf of a student, which is reflected on their character and satisfaction with it. A more harmonious correlation between the requirements of a college educational environment and students' opportunities also promotes a better expressed satisfaction with one's abilities. In college students it is 8.2 on average, while in university students it is 4.4 .

Let us draw our attention to the results of correlation analysis (Table 1). In a group of college students we uncovered a lot of statistically significant interconnections between the index of emotional well-being and self-assessment of significance and probability of life events. Expressed emotional well-being in this group is linked to general satisfaction with one's life $(r=-.508, p<.01)$, with satisfaction with inter-ethnic relations in the region of residence $(r=-, 259, p<.05)$, with high evaluation of an opportunity of career growth and achievement of material wealth $(r=-, 229, p<0,05)$, with evaluation of an ability and opportunity to influence one's life processes $(r=-, 31, p<.01)$, with ability and opportunity to influence the events, which are taking place in the society $(r=-, 31, p<.01)$, evaluation of an opportunity of selfrealization in professional activity $(r=-.27, p<.05)$, with positive experiences linked to progressive development of the society $(r=-.24, p<0,05)$, with hope for changes for the better in the society and in the world $(r=-0,263, p<0,05)$, with high evaluation of a possibility of interesting life in the present $(r=-.35, p<.01)$ and the future $(r=-.222, p<.05)$, with acceptance of the growing rhythm of life in the society $(r=-.25, p<.05)$, as well as with high evaluations of characteristics of an educational environment and high level of self-attitude.

It is evident that emotional well-being is widely determined by emotional and evaluative attitudes of a personality to events, which are taking place in the society in general and in the region of residence. High evaluation of a possibility to somehow influence what is happening and hope for positive changes strengthen this determination.

Significant factors in the development of personal emotional well-being in college are dynamism of life and satisfaction with components of educational environment: social component represented by teachers $(r=-.37, p<.01)$, content-related component $(r=-.44, p<.01)$, material and physical component (from $r=-.34, p<.01$ to $r=-.22, p<.05)$.

General psychological well-being in college students is associated with low degree of uncertainty in their life $(r=$ $.22, p<.05)$ and with humanness and warmth of contacts between people in the modern society $(r=-.21, p<.05)$.

The structure of interconnections between emotional and psychological well-being with evaluations of various events in the environment is changing in the group of university students. New interconnections appear. Thus, emotional well-being is linked to readiness to give help to those who need it $(r=-.231, p<.05)$, strength of positive emotions linked 
to progressive development of the society $(r=-.19, p<.05)$, hope for changes for the better in the society and in the world $(r=-.21, p<.05)$, possibility of close interpersonal communication in modern people $(r=-.22, p<.05)$, attitude to students on behalf of the society $(r=-.25, p<.05)$. It is obvious that emotional well-being has a lot of interconnections with social events and development of the society in general.

Subjective psychological well-being of university students is directly interconnected with significance of attitude of foreign countries to Russia and Russians $(r=.20, p<.05)$, significance of interpersonal relations under conditions of study, work, informal relations $(r=.21, p<.05)$, significance of ecological problem on the planet and in the region of residence $(r=.20, p<.05)$, readiness to help to those who need it $(r=.22, p<.05)$, opportunity of self-realization in professional activity $(r=.38, p<.01)$, positive experiences linked to progressive development of the society $(r=.41, p<$ .01), hope for changes for the better in the society and in the world $(r=.19, p<.05)$, humanness and warmth of contacts between people in the modern society $(r=.35, p<.01)$. We can trace the same tendency of interconnection between psychological well-being and attitudes of university students to social events in the modern society and social interconnections. The factor of self-realization in the professional sphere is added as well.

Table 2. Predictors of college students' emotional well-being

\begin{tabular}{|c|c|c|c|c|c|}
\hline & \multicolumn{3}{|c|}{ Non-Standardized coefficients Standardized coefficients } & \multirow[b]{2}{*}{$\mathrm{t}$} & \multirow{2}{*}{ Sig. } \\
\hline & $\mathrm{B}$ & Std. error & Beta & & \\
\hline (Const.) & 100.14 & 6.65 & & 15.06 & ,000 \\
\hline Satisfaction with life & 1.55 & .56 & .27 & 2.78 & ,007 \\
\hline Satisfaction with content of education that one receives & 1.85 & .55 & .29 & 3.37 & ,001 \\
\hline Satisfaction with one's character & 1.22 & .51 & .23 & 2.39 & 019 \\
\hline Opportunity of interesting full life in the present & 1.26 & .55 & .20 & 2.29 & ,025 \\
\hline
\end{tabular}

In order to describe predictors of emotional well-being in a group of college students (Table 2) we chose the regression model, which explains $44 \%\left(R^{2}=.44, F=15.59 p<.001\right)$ of dispersion.

General satisfaction with life, which is most likely linked to interest in events, richness of events in one's life, significantly increases emotional well-being of college students, which promotes the increase of emotional well-being. This is also fostered by the strongest predictor from the chosen model, which is satisfaction with content of education that one receives. This emphasizes the role of proper professional self-determination in formation of emotional well-being. Positive self-attitude, which is expressed in satisfaction with one's character, is a predictor linked to self-evaluation and reflection concerning relations and personal qualities.

Table 3. Predictors of emotional well-being in university students

\begin{tabular}{|c|c|c|c|c|c|}
\hline & \multicolumn{3}{|c|}{ Non-Standardized coefficients Standardized coefficients } & \multirow[b]{2}{*}{$\mathrm{t}$} & \multirow{2}{*}{ Sig. } \\
\hline & $\mathrm{B}$ & Std. error & Beta & & \\
\hline (Const.) & 40.69 & 7.70 & & 5.28 & .000 \\
\hline Opportunity of interesting full life in the future & -2.16 & .71 & -.36 & -3.05 & .008 \\
\hline Satisfaction with content of education that one receives & 1.99 & .52 & .44 & 3.84 & .001 \\
\hline Satisfaction with possibility to eat good food & -1.42 & .56 & -.31 & -2.52 & .023 \\
\hline Notion of happiness as peaceful quite life & 1.85 & .66 & .33 & 2.81 & .013 \\
\hline Significance of political stability in the region, state & -1.19 & .53 & -.29 & -2.27 & .038 \\
\hline
\end{tabular}

The regression model (Table 3), which describes the predictors of emotional well-being in university students explains $81 \%\left(\mathrm{R}^{2}=.81, \mathrm{~F}=13.82, \mathrm{p}<.001\right)$ of dispersion. Judging by the results of regression analysis we can come to the conclusion that emotional well-being of university students is largely conditioned by satisfaction with content of education that they receive, their notion of happiness as peaceful and quite life, while significance of political stability in the region and in the state, conviction regarding an opportunity of interesting and full life in the future, as well as satisfaction with possibility to eat good food decrease their emotional well-being.

\section{Discussion}

Results of comparative analysis of subjective well-being of college and university students attest to the fact that university students' subjective well-being is generally better than that of college students. This is obviously associated with their 
social status and opportunities of satisfying their needs, primarily social and cognitive (educational) ones.

Apart from that, the stage of university education is closer to the stage of independent work, while college education is perceived as a stage which is preceding university education by many students; this puts off the perspective of independent professional activity in time and decreases the experience of subjective well-being in the present.

University educational environment is more complicated and includes not only educational conditions, but also conditions for wide social contacts and creativity in addition to educational process. Moreover, it is highly probable that university students recognize the fact that in the future they will have more opportunities for employment, their work will be more prestigious and high-paid, which can serve as a foundation for higher social status. It is obvious that under conditions of college education there are fewer opportunities for satisfaction of these kinds of needs, therefore, general subjective well-being of students decreases significantly. These data correspond with investigations, which were carried out by Kozmina L.B. (2013) and Kornienko D.S., Kozlov A.I. (2014), Shamionov R.M. (2014). These works show that subjective well-being is related to positive professional and personal planning of students. At the same time college students can experience frustration because of friendship or insufficiently developed social skills (Demir, Jaafar, Bilyk \& Ariff, 2012).

The results of correlation analysis show that psychological well-being in college students in more stable in comparison with emotional well-being and is conditioned by certainty of events and interpersonal relations. At the same time such impoverished determination of psychological well-being does not allow its compensation and complementarity at the account of connections with other events of the surrounding reality.

In university students emotional well-being is also related to convictions, social needs and their satisfaction, but the number of significant interconnections is smaller than in college students (15 and 21 correspondingly). On the contrary, the number of significant interconnections between general psychological well-being and convictions, social needs and their satisfaction in a group of university students is 22 , while in a group of college students the number is 2 . This means that university students have a relatively wide determination of emotional well-being and general psychological wellbeing; there is an opportunity of flexible compensation, strengthening and increasing both types of well-being under conditions of strengthening some of the interconnections and weakening the others. One can observe significant involvement of psychological well-being into life events and evaluation of these events, which corresponds with data presented by Kozmina (2013). Psychological well-being in university students is therefore more substantiated and supported by personal evaluations and attitudes, than that of college students. Such dependence is not occasional due to the fact that psychological well-being presupposes more significant autonomy, competence, and personal growth (Ryff, \& Keyes, 1995; Ryff, \& Singer, 2006).

Results of correlation analysis show that emotional well-being in a group of university students is largely conditioned by social relations and convictions, social needs and their satisfaction. On the one hand, it signifies greater social maturity of university students in comparison with college students. On the other hand, under conditions of social instability and tension it can serve as an essential foundation for more expressed emotional ill-being. In comparison to a group of college students, university students demonstrate more new interconnections between general subjective wellbeing and personal convictions.

Having compared regression models of emotional well-being in the groups of college and university students, we have to point out that the prediction of emotional well-being varied. We singled out only one similar predictor, which is relatively equal for both groups. It is satisfaction with content of education that students receive. In university students prediction of emotional well-being is more complicated, controversial; it unites factors, which involve with both sociopolitical conditions and satisfaction of vital needs. Emotional well-being of university students is strengthened by satisfaction with content of education, their conviction regarding the fact that happiness is peace, enjoyment, lack of any effort. Thus, university students attribute the increase in emotional well-being to things that they learn, to knowledge that they receive, and the decrease of their personal activity and effort.

Emotional ill-being is fostered by an opportunity of interesting full life in the future, possibility to eat good food, importance of political stability in the region and in the state. Interconnection between emotional ill-being and importance of political stability in the region and in the state for a person can be explained by anxiousness, which is caused by political instability. The higher the significance of political stability, the higher the level of anxiety related to impairment of stability is.

It is more difficult to explain the interconnection between emotional ill-being and opportunity of interesting full life in the future and possibility to eat good food. In the first case, it could probably be explained by lack of readiness in university students for a full life in the future, unwillingness to accept tension, which is growing in informative and active situation. In the second case a possibility to eat good food is obviously perceived by university students as a potential possibility, which is difficult to realize in their real lives. 


\section{Conclusion}

The differences between emotional well-being of college and university students, which are conditioned by significance of convictions and satisfaction of urgent needs, are combined with indifference to their psychological well-being. University students generally feel more subjectively well than college students.

The notions regarding the way of achieving subjective well-being differ for college and university students. College students link the achievement of subjective well-being with easiness of satisfaction of one's needs, lack of difficulties in achieving one's goals and general lack of problems in life.

Educational environment is an important factor for subjective well-being. College students are more satisfied with social and material components of their educational environment, while university students are more satisfied with the content of education that they receive.

Evaluations of significance of life events and personal attitudes are mostly linked to emotional well-being for college students; while for university students they are related to both emotional and psychological well-being.

Prediction of emotional well-being for college students is more complicated and controversial; it unites factors, which deal with socio-political convictions and satisfaction of vital needs.

\section{Acknowledgements}

The study was supported by the Russian Foundation for Humanities, project № 15-06-10624a.

\section{References}

Argyle, M. (2001) The psychology of happiness (2nd Edition). London: Routledge.

Brisset, C., Safdar, S., Lewis, J. R., \& Sabatier, C. (2010) Psychological and sociocultural adaptation of university students in France: The case of Vietnamese international students. International journal of intercultural relations, 34(4): 413-426.

Busseri, M.A., Sadava, S.W. (2013) Subjective well-being as a Dynamic and Agentic System: Evidence from a Longitudinal Study. Journal of happiness studies, 14(4): 1085-1112.

Butkovic, A., Brkovic, I., Bratko, D. (2012) Predicting well-being From Personality in Adolescents and Older Adults. Journal of happiness studies, 13(3): 455-467.

Chebanova, G.V. (2014) Student's emotional entelligence whith differen subjective well-being. Applied psychology and psychoanalysis, 4. 4 [Online] http://www.ppip.idnk.rul (May 27, 2015)

Chen, F.F., Jing, Y., Hayes, A., Lee J.M. (2013) Two Concepts or Two Approaches? A Bifactor Analysis of Psychological and Subjective well-being. Journal of happiness studies, 14(3): 1033-1068.

Demir, M., Jaafar, J., Bilyk, N. \& Ariff, M.R. (2012) Social Skills, Friendship and Happiness: A Cross-Cultural Investigation. The Journal of Social Psychology, 2012, 152(3): 379-385.

Diener, E., \& Lucas, R. E. (1999). Personality and subjective well-being: The foundations of hedonic psychology. In D. Kahneman \& E. Diener (Eds.), Well-being: The foundations of hedonic psychology (pp. 213-229). New York: Russell Sage Foundation.

Dorozhkin, Iu. N., \& Mazitova, L. T. (2008) Problems of the Social Adaptation of Foreign College Students. Russian Education and Society, 50(2): 23-30.

Hui, K., Lent, R.W., Miller, M.J. (2013)Social Cognitive and Cultural Orientation Predictors of well-being in Asian American College Students. Journal of career assessment, 21(4): 587-598.

Kornienko, D.S., Kozlov, A.I. (2014) Social and Regional Differences in Psychological Well-being Among Students. Modern problems of science and education, 5: 649. [Online] http://www.science-education.ru (May 27, 2015)

Kozmina, L.B. (2013) Dynamics of psychological wellbeing of students with major in psychology during their education in a higher school. The theory and practice of social development, 11: 118-120.

Ovchinnikov, A.A., Sultanova, A.N. (2014) Comparative analysis of psychological well-being and strategy of adaptation of migrant students and titular ethnic students. Medicine and Education in Siberia, 2014. 4: 15. [Online] http://mos.ngmu.ru (May 27, 2015)

Perrudet-Badoux, A., Mendelsohn, G. Chiche, J. (1988) Développement et validation dune échelle pour Vévaluation subjective du bienêtre Cak Antkropol Biomet Hum, 3: 121-134

Pogorskaya, V.A. (2011) Relationship between subjective well-being and value-semantic scope of personal students of pedagogical professions. Vector of Science of Togliatti State University. Series: Pedagogics, Psychology, 3: 252-254.

Ryff, C. D., \& Keyes, C. L. M. (1995). The structure of psychological well-being revisited. Journal of Personality and Social Psychology, 69: 719-727.

Ryff, C. D., \& Singer, B. H. (2006). Best news yet on the six-factor model of well-being. Social Science Research, 35: 1103-1119.

Safronova M.V., Kuznetsova V.B. (2014) Personal characteristics and problems psychosocial well-being of young boys and girls studying in a higher educational institution. Psychologiya obucheniya, 12: 67-76.

Shamionov, R.M. (2014) Adaptational Potential and Subjective Well-Being Of Comprehensive School Graduates And First Year Students Of Higher Educational Institutions. Procedia - Social and Behavioral Sciences, 131: 51 - 56. 
Shamionov, R.M., Grigoryeva, M.V., Grigoryev, A.V. (2014) Influence of beliefs and motivation on social-psychological adaptation among university students. Procedia - Social and Behavioral Sciences, 112: 323-332.

Sheldon, K.M., Cheng C., Hilpert J. (2011) Understanding well-being and optimal functioning: Applying the multilevel personality in context (MPIC) model. Psychological Inquiry, 22(1): 1-16.

Sheldon, K.M., Hoon T.H. (2007) The multiple determination of well-being: independent effects of positive traits, needs, goals, selves, social supports, and cultural context. Journal of Happiness Studies, 8: 565-592.

Shoshani, A., Slone, M. (2013) Middle School Transition from the Strengths Perspective: Young Adolescents' Character Strengths, Subjective well-being, and School Adjustment. Journal of happiness studies, 14(4): 1163-1181.

Sokolova, M.V. The scale of subjective well-being. Yaroslavl: Yar.univ.; 1996.

Urivaev, V.A., Tarasova, A.A (2011) The subjective well-being and the structure of defensive reactions in medical academy students personality. Siberian Journal of Psychology, 41: 58-63.

Vodyakha, S.A. (2014) Correlation of Students' strengths of character with indicators of Psychological well-being. Pedagogical Education in Russia, 2: 96-99.

Wouters, S., Germeijs, V., Colpin, H., \& Verschueren, K. (2011) Academic self-concept in high school: Predictors and effects on adjustment in higher education. Scandinavian journal of psychology, 52(6): 586-594.

Yashchenko, E.F. (2012) Self-actualization and subjective wellbeing as socially-psychological problems of professional education: university students and lecturers. The Herald of South Ural State University. Series: Psychology, 31: 56-63.

Yu, B., \& Downing, K. (2012) Determinants of international student's adaptation: examining effects of integrative motivation, instrumental motivation and second language proficiency. Educational studies, 38(4): 457-471. 